\title{
The effect of fun and interactive games as a strategy in teaching coordinates to enhance students' performance in Mathematics
}

El efecto de los juegos divertidos e interactivos como estrategia en la enseñanza de coordenadas para mejorar el rendimiento de los estudiantes en Matemáticas

\author{
Nurjailam Hamzah \\ Universiti Kebangsaan Malaysia - Malaysia \\ jaiondeline@yahoo.com.my \\ Siti Mistima Maat* \\ Universiti Kebangsaan Malaysia - Malaysia \\ sitimistima@ukm.edu.my \\ Zanaton H Iksan \\ Universiti Kebangsaan Malaysia - Malaysia \\ zanaton.iksan@ukm.edu.my
}

\begin{abstract}
This research is aimed to help students develop their mathematical concept, as well as emphasizing the appropriate use of information technology among Year Three students. The current mathematics curriculum in Year Three primary school in Malaysia was introduced in 2018. This quantitative study used a quasi-experimental method. Thus, this study examines the differences in performance between a controlled group and experimental group from a school in Malaysia. Paired samples test results have proven that the experimental group performed better than the controlled group. It was also found that fun and interactive games can increase students' understanding and interest towards mathematics. Interactive games can contribute least time to master some mathematical concepts in a fun way. Therefore, the fun and interactive game is a superior instrument that can be utilized by primary students in learning mathematics in order to encourage learning and innovation skills in the 21 st century.
\end{abstract}

Keywords: fun and interactive games, students' mathematics performance.

\section{RESUMEN}

Esta investigación tiene como objetivo ayudar a los estudiantes a desarrollar su concepto matemático, así como enfatizar el uso apropiado de la tecnología de la información entre los estudiantes de tercer año. El plan de estudios matemático actual en la escuela primaria del tercer año en Malasia se introdujo en 2018. Este estudio cuantitativo utilizó un método cuasi-experimental. Por lo tanto, este estudio examina las diferencias en el rendimiento entre un grupo controlado y un grupo experimental de una escuela en Malasia. Los resultados de las pruebas de muestras emparejadas han demostrado que el grupo experimental se desempeñó mejor que el grupo controlado. También se descubrió que los juegos divertidos e interactivos pueden aumentar la comprensión e interés de los estudiantes hacia las matemáticas. Los juegos interactivos pueden aportar menos tiempo para dominar algunos conceptos matemáticos de una manera divertida. Por lo tanto, el juego divertido e interactivo es un instrumento superior que los estudiantes de primaria pueden utilizar en el aprendizaje de las matemáticas para fomentar las habilidades de aprendizaje e innovación en el siglo XXI.

Palabras clave: juegos divertidos e interactivos, rendimiento matemático de los alumnos. 


\section{INTRODUCTION}

Education is essential to every developing country. Achieving the high-performing education system would put Malaysia on the same level as other developed countries. The desires of Malaysia to be in the top third nations as far as execution in universal evaluations as estimated by results in Trends in International Mathematics and Science Study (TIMSS) and Program for International Student Assessment (PISA) within 15 years. Extra evaluations that address different elements of value that are important to the Malaysian setting might be incorporated as they are created and being acknowledged worldwide models (Pelan Pembangunan Pendidikan Malaysia (PPPM) 2013-2025).

In order to achieve the purpose of PPPM 2013-2025, the Ministry of Education had decided to revise the mathematics curriculum by introducing the new learning areas which are relationship and algebra. Ratio and proportion as well as coordinates are two new topics that need to be learned by the nine years old students. As a professional educator, teachers need to use their creativity to achieve the objectives of the lesson as stated in the standard curriculum document. BPK (2017) mentioned that teachers are advised to use a variety of sources such as modules, books and the internet to provide suitable teaching and learning activities.

One of the aspirations of Primary School Standard Curriculum is to produce pupils with the 21 st century skills by focusing on creative thinking skills, living skills and career guidance that are based on practical moral values. On the other hand, $21 \mathrm{st}$ century skills aim to prepare students with the needed characteristics such as being resilient, communication skills, thinking skills, teamwork, and curiosity, principled, informative, and attentive as well as patriotism to ensure that they are able to compete globally. Mastering the Content of Standard (CS) and Learning Standard (LS) in the primary school mathematical curriculum contributes to the acquisition of 21st century skills among pupils (Pelan Pembangunan Pendidikan Malaysia (PPPM) 2013-2025)

Benefits of Games: Games are the most talked and played medium not only by adults but to children as well. A fun and interactive game is a game intended to show individuals a particular subject and to show them an expertise (Keesee, 2012). Educational games are intended for learning and to engage in enhancing students' performance in mathematics. The fun and interactive games can support understudies' inspiration, and furthermore can urge them to learn at their very own pace (Brawerman et al., 2013). Based on Prensky (2001), games are a subset of play and fun where there are six essential segments of games, which comprise of guidelines, objectives or destinations, results or criticism, strives, rivalry, challenge, cooperation, and portrayal or story. Theories of collaboration exist at the interfirm and intergroup level, but not the intragroup or team level (Colbry et al. 2014). This mean that games is a part of communication among students to work and to solve the problems as a team not to provoke someone to acheive the goals of learning.

Teaching new STEM topic to young students is not an easy way for teachers in order to deliver the mathematical concepts. Based on the study by Cita and Subiyanto (2017), both found that from the experimental group findings, the creation of android instructive games can improve understudies' perusing capacity in the medium class. In this way, the android instructive game can be utilized as an elective apparatus for picking up perusing which is superior to a book. In a way to improve pupils' performance in mathematics, researcher wants to examine the effect of teaching coordinates using online and other educational games in teaching coordinates topic.

Gros (2007) stated that students improve slightly and show changes in their habits by far from the previous. Nowadays, children have started to use visual electronic devices such as computers, tablets, digital music players and of course educational games since their toddler age. Educational interactive games is a type of helpful tools, as children gain from a youthful age on the most proficient method to pursue explicit methodologies to accomplish their objectives. In addition, when students engage with the educational interactive games routinely, it contributes to the improvement of visual attention as the user is able to focus on different matter at the same time. Therefore, educational games can give big impact to those young students that having difficulties to understand the mathematical concept abstractly.

\section{METHODOLOGY}

The purpose of this study is to scrutinize the effect on students' performance towards mathematics when online and other interactive games are utilized in teaching coordinates. This descriptive study was implemented to identify the Year Three students' understanding in coordinates topic through the interactive games. The quantitative method of pre and post-test were used to collect the data. A set of 21 questions were used in the pre and post-test for both controlled and experimental groups. The used of quasi-experimental method using pre-test and post-test is easily to assist the researcher to obtain and to analyse the data.

The research was implemented on a total of 60 Year Three students that were studying in two different classes at the same primary school located in Malacca. The participant in this study are formed by nine years old students those learning mathematics in SK syllabus. Both classes formed by mix abilities students. Seventeen (56.7\%) students were male and thirteen $(43.3 \%)$ were female in the experimental group. Meanwhile in the controlled group, fourteen (46.7\%) students were male and 16 (53.3\%) students were female. 60 students were formed to be in the controlled group and experimental group. Matching and stratifying groups require researchers to match participants in each group on as many characteristics as possible to ensure that control and experiment groups are as similar as possible before the treatment is introduced (Shadish et al., 2002). In this study, the two classes were selected from the same school, where the students in both classes have similiar scores in mathematics performance and the teachers that teach them have similiar teaching styles. The controlled group consisted of 30 students was not affected by the independent variable. While the experimental group consists of 30 students was affected with teaching using online and educational interactive games. The size of the sample in quantitative study typically follows random sampling procedures is enough to carry out one's study (Cresswell, 2015). To implement the pre-test and post-test in order to determine whether any significant differences exist, the hypotheses were tried by looking 
at the variety in score (Bulduk

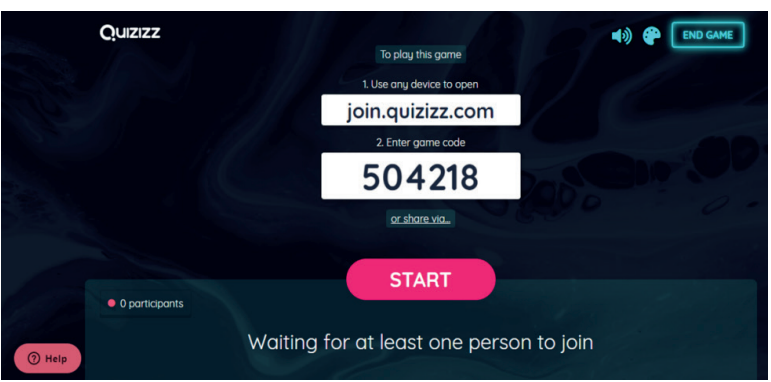

Figure 1: Code used to enter and answer the questions

\section{Procedures}

A topic in Relationship and Algebra Learning Area that was "Coordinates" was chosen for this study. This topic is selected because it was a new STEM topic introduced in Year Three syllabus. In identifying that this topic should be used, two variables were taken into consideration. Firstly, according to the current mathematics standard curriculum in Malaysia (BPK 2017), Year Three students relied upon to the knowledge and mathematical skills to solve problems related to coordinates, give mathematical reasoning, make connections, make representations, communicate and use technology to solve the situation involving coordinates. Secondly, studies' findings have revealed that students had trouble in this topic (Monk 1992; Oehrtman et al. 2008; Dubinsky \& Wilson 2013). According to Moore and Thompson (2005), the conventional activity of plotting point by moving over $\mathrm{x}$ units and up y units did not support students in engaging in an em

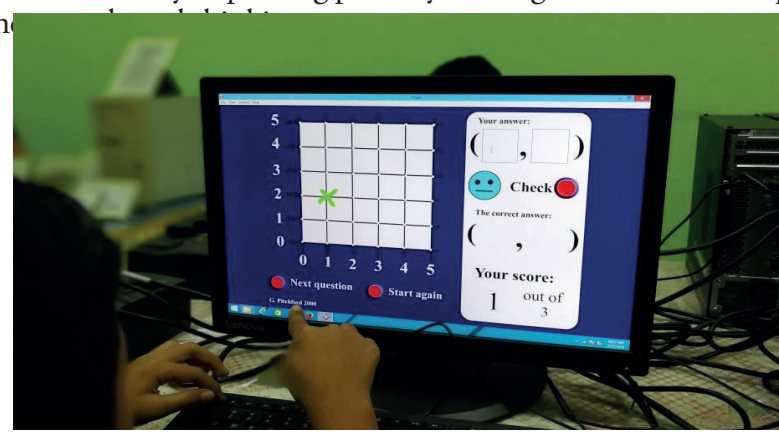

Figure 2: Teaching coordinates using games by students in experimental group

For the controlled group, classes were taught using conventional activities via online and educational interactive games were used on the experimental group. The educational games were prepared in the form of flash player and projected on a screen using LCD projector and with sounds as an interesting element to attract students' attention. The Mathematics Performance Test (MPT) consisted of 21 questions were developed using the Quizizz Online. Students needed to enter the special code to answer the questions and the test was conducted in the computer lab. Time was given to them to solve all the questions. The pre-test result was obtained from both groups, then the same set of questions was also used in order to get the results for the post-test. Analysis of data gathered by students from the Mathematics Performance Test from pre-test and post-test were evaluated using the Statistical Package for the Social Sciences (SPSS) software on a computer. The independent group t-test was used in paired comparisons between different groups and dependent group t-test in paired comparisons within the groups themselves depending on the type of data. Differences between the experimental and controlled groups were found to have significant level of $\mathrm{p}<.05$ according to the relevant variables.

\section{RESEARCH FINDINGS}

Before conducting the independent samples t-test and the paired samples t-test, the normal distribution test was implemented. Drezner et al. (2008) stated one of the most frequently used tests to evaluate how far is the data are from normality is the Kolmogorov-Smirnov (K-S) test. A set of data is normally distributed with a mean of 5. Kolmogorov-Smirnov (K-S) test was used to assess the normality of the distribution of scores in the sample to a normally distributed sets of scores with the same mean and standard deviation. K-S test is to compare statistical distribution on the result of Mathematics Performance Test to two groups of study. The results of normality using $\mathrm{K}-\mathrm{S}$ test on the controlled group and the experimental group are as follows: Kolmogorov-Smirnov test $(\mathrm{P}=0.088)$ and Kolmogorov-Smirnov test $(\mathrm{P}=0.149)$, while the results of the Kolmogorov-Smirnov test which were conducted on the results of the post-test are as follows: Kolmogorov-Smirnov test $(\mathrm{P}=0.183)$ and Kolmogorov-Smirnov test $(\mathrm{P}=0.148)$. The tests for pre-test and post-test show that the tests are non-significance where $\mathrm{p}>0.05$. This indicates that the samples are not significantly different and can be assumed to be normally distributed. Since the tests shown 
are normally distributed, it was decided to use the t-test in the next analysis to answer the objectives of the study.

The results of the independent group t-test implemented on the MPT for pre-test scores of the controlled and experimental groups show no significant difference, as there is only a statistical level of significance of 0.05 in terms of the performance toward mathematics between the two groups $\mathrm{t}(58)=0.823$ which has proven to be statistically insignificant $(\mathrm{p}=.414)$. The mean difference score between the controlled and experimental group is 1.633 only which the above data shows the controlled group students $(\mathrm{x}=19.30)$ were more excellent in pre-test of mathematics performance compared to students in experimental group $(\mathrm{x}=17.67)$. This shows that both groups' performance toward mathematics are equal prior to introducing teaching using interactive games.

According to the scores obtained by the experimental and controlled groups from the subdimensions of the pre-test based on the paired sample t-test results, students' mathematics performance in controlled group for pre-test and posttest respectively $\mathrm{t}(29)=33.079$ proved to be statistically significant $(\mathrm{p}<.05)$ and the result for students' mathematics performance in experimental group for pre-test and post-test respectively $\mathrm{t}(29)=-33.174$ is also proven to be statistically significant $(\mathrm{p}<.05)$. Both results show that there are significant differences between controlled and experimental groups before and after the lesson implemented. According to the mean score obtained by the controlled group $(\mathrm{x}=63.700)$ and experimental group $(\mathrm{x}=-67.533)$, it shows that the experimental group has higher of mean score compared to the controlled group. This data indicates that conventional teaching method can develop students' understanding and performance but teaching the coordinates using educational interactive games can promote interesting lessons which will also contribute to the development of students' performance.

\section{DISCUSSION AND CONCLUSION}

This investigation is embraced, as it is important to the current as well as the future needs of the country especially in terms of economical instruction (Muhammad Ridhuan et. al. 2012). The choice made by the analyst in choosing the topic to be studied is likewise founded on the thought of specially explored zones in education particularly related to innovation of upgraded advancement in primary education. Studies conducted have shown that there has been a significant positive relation between the students' performance in the pre-test and post-test for both group studies. It was found that the mean score increased higher for the experimental group compared to the controlled group. This result shows that teaching using interactive games has positively influenced students' interest towards mathematics and they can also explore the mathematical concepts of coordinates at their own pace. They also played the interactive games during their leisure time either at home or school. Regardless of the format of the game, students can simultaneously build their mathematical concepts while having fun throughout the process as long as the interactive games are welldesigned (MacKenty, 2006, Harris, 2009). Therefore, interactive games can contribute least time to develop some mathematical concepts in a fun learning environment.

Students in experimental group had higher mean score difference compared to the controlled group because students in experimental group have several positive features such as cooperative game playing and interpersonal competitive playing. These features are important in 21st century learning where cooperation is a part of labour between group members. It occurs when a task is splited up into individually manageable subparts, which are subsequently developed into a final outcome. Despite the fact that this is conceptually different to collaboration, at a fine-grained level, all collaborative tasks have a degree of cooperation (Lai \& Viering, 2012). To support genuine collaboration effort (which would then be able to be observed and measured) assessors need to control bunch individuals' encounters with each other so channels of communication and shared comprehension are improved before appraisal begins. (Simon and Stuart 2016).

In conclusion, from the discoveries of this study, interactive games are perceived as a powerful classroom-learning tool, which expedite critical and positive outcome on students' retention and mastery of coordinates topic as compared to students who rely only upon conventional classroom instructions.

As suggestion, teachers should consider using the educational interactive games or other online games in their classroom to improve the students' self-efficacy in studying mathematics, which has positive correlation with their learning achievement. The present study only investigates the effects of teaching coordinates via online and other educational interactive games on students' achievement in mathematics without further analysing what factors that cause such effects. Future research is suggested to start considering and investigating such factors to obtain more interactive tools to apply in the teaching and learning process to enhance students' performance in mathematics.

\section{ACKNOWLEDGEMENT}

This work is funded by Universiti Kebangsaan Malaysia grant GG-2019-065 


\section{BIBLIOGRAPHIC REFERENCES}

Ali, S., \& Maat, S. M. (2019). Exploring the 21st Century Teaching and Learning Practice among Mathematics Secondary School Teachers. International Journal of Academic Research in Progressive Education and Development, 8(2), 361-378.

Bahagian Pembangunan Kurikulum (2017). Kurikulum Standard Sekolah Rendah: Dokumen Standard Kurikulum dan Pentaksiran Matematik Tahun 3 (Edisi Bahasa Inggeris). Putrajaya: Kementerian Pendidikan Malaysia

Brawerman, A., Bortoloti, C., Guimaraes, L. B., Granato, L. C., Aroldi, M. D., \& de Sauza, V. M. (2013). ABC gameeducating through mobile devices. In International Conference on Interactive Computer Aided Blended Learning. (146-150).

Bulduk, S. (2003). Psikolojide deneysel araștırma yöntemleri. İstanbul: Çantay Kitabevi.

Christensen, L. B. (2004). Experimental methodology. Boston. MA: Pearson Allyn \& Bacon.

Cita Puspitasari \& Subiyanto (2017). A New Tool to Facilitate Learning Reading for Early Childhood. Malaysian Online Journal of Educational Technology. 5(3),1-15

Colbry, Stephanie \& College, Cabrini \& Adair, Rodger. (2014). Collaboration Theory. The Journal of Leadership Education. 13, 63-75.

Creswell, John W. (2015). Educational research: Planning, conducting, and evaluating quantitative and qualitative research (5th ed.). Boston, MA: Pearson.

Drezner, Zvi \& Turel, Ofir \& Zerom, Dawit. (2008). A Modified Kolmogorov-Smirnov Test for Normality. Germany: University Library of Munich.

Fraenkel, J. R., \& Wallen, N. E. (1993). How to design and evaluate research in education (2nd ed.). Boston, MA: McGraw Hill.

Gros, B. (2007). Digital games in education: The design of gamesbased learning environments. Journal of Research on Technology in Education, 40(1), 23-38. http://dx.doi.org/10.1080/15391523. 2007.10782494

Harris, C. (2009). Meet the New School Board: Board games are back - and they're exactly what your curriculum needs. School Library Journal, 55, 24-26. https://images.pearsonassessments.com/images/tmrs/Assessing_21st_ Century_Skills_NCME.pdf

Jasni, S.R, Zailani,S. \& Zainal, H. (2018). Gamification Approach In Learning Arabic Language. Journal of Fatwa Management and Research.

Keesee,G.S.(2012).Educational Games.Retrieved http://teachinglearningresources.pbworks.com/w/page/35130965/ Educational\%20Games

Kementerian Pendidikan Malaysia (2012). Laporan awal pelan pembangunan pendidikan Malaysia 2013-2025. Putrajaya, Malaysia. Retrieved from http://www.moe.edu.my/btp/wp-content/uploads/2012/Blueprint/PreliminaryBlueprint-BM.pdf

Khaleel, F.L., Ashaari, N.S., Wook, T.S.M.T., Ismail, A. (2016).Gamification elements for learning applications. International Journal on Advanced Science, Engineering and Information Technology. 6(6), 864-874

Khaleel, F.L., Ashaari, N.S., \& Wook, T.S.M.T., (2019). An empirical study on gamification for learning programming language website. Jurnal Teknologi. 81(2), 151-162

Laal, Marjan \& Laal, Mozhgan \& Khattami Kermanshahi, Zhina. (2012). 21st Century Learning; Learning in Collaboration. Procedia - Social and Behavioral Sciences. 47. 1696-1701. 10.1016/j.sbspro.2012.06.885.

Lai, E. R. \& Viering, M. (2012). Assessing 21st Century Skills: Integrating Research Findings. National Council on Measurement in Education. Vancouver, B.C. 1-66. Retrieved from

MacKenty, B. (2006). All Play and No Work. School Library Journal, 52, 46-48.

Monk, S. (1992). Students' understanding of a function given by a physical model. In G. Harel \& E. Dubinsky (Eds.), The concept of function: Aspects of epistemology and pedagogy. MAA Notes, 25, 175-193).

Muslimin,M.S., Nordin, N.M, Mansor, A.Z \& Yunus, M.M. (2017).The Design And Development Of Mobieko: A Mobile Educational App For Microeconomics Module. Malaysian Journal of Learning and Instruction: Special Issues .221-255

Oehrtman, M., Carlson, M \& Thompson,P.W.(2008). Foundational Reasoning Abilities that Promote Coherence in Students' Function Understanding. In M. P. Carlson \& C. L. Ramussen (Eds.) Making the Connections: Research and Teaching in Undergraduate Mathematics Education. Washington: Mathematical Association of America.

Prensky, M. (2001). Digital Game-Based Learning. New York, NY: McGraw-Hill.

Ridhuan, M., Lim, T., Bakar, Z. A., Ali, R. M., Faye, I., \& Hasan, H. (2012). The Impact of Video Games in Children's Learning of Mathematics. World Academy of Science, Engineering and Technology International Journal of Educational and Pedagogical Sciences. 6(4), 607-613.

Shadish, W., Cook, T., \& Campbell, D. (2002). Experimental and Quasi-experimental designs for generalized causal inference. Boston: Houghton Mifflin Company.

Simon, C. \& Stuart, S. (2016). Collaboration in the 21st century: Implications for assessment. Research Matters: $A$ Cambridge Assessment publication. (22). 17-22.

Wong, W.S \& Kamisah, O. (2018). Pembelajaran Berasaskan Permainan dalam Pendidikan STEM dan Penguasaan Kemahiran Abad Ke-21. Politeknik \& Kolej Komuniti Journal of Social Sciences and Humanities. 3, 121-135. 